\title{
The Dilemma of Inadvertent Pontine Demyelinosis: A Review of Literature
}

Abu Baker Sheikh ${ }^{1}$, Rao M. Afzal ${ }^{2}$, Shazib Sagheer ${ }^{3}$, Marvi M. Bukhari ${ }^{2}$, Anam Javed ${ }^{4}$, Adeel Nasrullah ${ }^{5}$ , Usman Tariq ${ }^{6}$, Fahad Athar ${ }^{7}$, Muhammad Sabih Saleem ${ }^{8}$

1. Internal Medicine, University of New Mexico, Albuquerque, USA 2. Internal Medicine, Shifa College of Medicine, Islamabad, PAK 3. Internal Medicine, University of New Mexico Hospital, Albuquerque, USA 4. Internal Medicine, College of Medicine and Dentistry, University of Lahore, Lahore, PAK 5. Internal Medicine, Allegheny General Hospital, Pittsburgh, USA 6. Research Assistant, Yale University School of Medicine, New Haven, USA 7. Other, Albert Einstein Medical Center, Philadelphia, USA 8. Medicine, Shifa International Hospital, Islamabad, PAK

Corresponding author: Abu Baker Sheikh, drabubakersheikh@gmail.com

\section{Abstract}

Osmotic demyelination syndrome is classically associated with a swift adjustment of previously low serum sodium levels which lead to cellular dehydration and subsequent neurological insult. We also review the epidemiology, different postulations to explain the underlying pathophysiology, current diagnostic modalities, subsequent therapeutic interventions used to manage this phenomenon, and the resultant prognosis of this ailment.

Categories: Internal Medicine, Neurology

Keywords: osmotic demyelination syndrome, sodium correction

\section{Introduction And Background}

Osmotic demyelination syndrome (ODS) characteristically affects the central pons symmetrically, but can also affect other areas of the brain such as the basal ganglia, thalamus, and lateral geniculate bodies. It is mainly observed in patients with underlying issues such as alcoholism, malnourishment, and/or a previously unceasing illness. However, the most common affiliate is robust fluid and electrolyte replenishment as most patients have hyponatremia as a frequent affiliate [1].

\section{Review}

\section{Epidemiology}

Osmotic demyelination syndrome (ODS) is a noninflammatory demyelinating disease that usually involves the base of the pons (central pontine myelinolysis, CPM) and may often extend to the extrapontine structures (extrapontine myelinolysis, EPM) [1-4]. It is a rare condition that has an undetermined incidence, with many cases diagnosed via autopsy [5]. Although it was first described by Adams et al. as a solely pontine entity, an autopsy study in 1987 that included 58 cases of ODS described the presence of CPM in half, a combination of CPM and EPM in 30\%, and isolated EPM in 20\% of the cases [6-7]. However, in clinical practice, EPM is a rare find with an incidence of less than $10 \%$ in patients suffering from CPM. An important factor contributing to this rarity is the masking of EPM symptoms by a concomitant pontine dysfunction [8-

Received 08/13/2018

Review began 08/17/2018 Review ended 08/17/2018 Published 08/21/2018

\section{() Copyright 2018}

Sheikh et al. This is an open access article distributed under the terms of the Creative Commons Attribution License CC-BY 3.0., which permits unrestricted use, distribution, and reproduction in any medium, provided the original author and source are credited. 9].

\section{Clinical presentation}

The clinical presentation of ODS is highly variable and dependent on the region of the brain that is affected. The spectrum of presentations ranges from an asymptomatic clinical picture to severe outcomes such as coma and death. The typical presentation is of paraparesis or quadriparesis accompanied by symptoms of pseudobulbar palsy including dysarthria and dysphagia [5]. CPM can also lead to 'locked-in syndrome,' a state of preserved consciousness along with the paralysis of all voluntary movement except the eyes. On the other hand, EPM can present with cognitive dysfunction, myoclonus, dystonia, parkinsonism, and choreoathetosis [8, 10-11]. In some cases, the only evidence of EPM is nonspecific symptoms such as lethargy or altered mood which underscores the need for a high clinical suspicion in the setting of vague symptoms in patients undergoing an electrolyte replenishment [12].

\section{Pathophysiology}

The precise pathophysiology of this syndrome is yet to be fully elucidated. Postulated theories include the adaptation of the brain to chronically low levels of the intracellular osmolyte. A subsequent exposure to hypertonic stress resulting from a rapid correction of hyponatremia causes the ions to quickly re-enter the intracellular space and compels the water to follow. As this occurs, the intracellular sodium and chloride levels rise to a higher than normal value resulting in cellular dehydration [1, 13-15]. 
Disruption of the blood-brain barrier is also considered to be a key component in the pathogenesis, followed by oligodendrocyte degeneration, an influx of macrophages, and degradation of myelin [14-16]. ODS occurs most frequently due to osmotic damage following a rapid correction of hyponatremia which is defined as a correction by more than $12 \mathrm{mEq} / \mathrm{L} /$ day and/or $18 \mathrm{mEq} / \mathrm{L}$ in 48 hours [17]. However, it is not solely due to rapid correction of hyponatremia, as there have been reported cases, albeit rare, such as ours, in which ODS developed despite correction of serum sodium according to the proposed guidelines [18].

\section{Diagnosis}

The main diagnostic modality employed is a brain magnetic resonance imaging (MRI) scan. T1-weighted images will show the symmetric hypointense lesions, meanwhile T2-weighted images have symmetric hyperintense lesions [19-21]. The characteristic "bat-winged" or "trident-shaped" appearance in the center of the pons is the classic finding on MRI for CPM [22]. Moreover, a retrospective study concluded that patients with high clinical suspicion of ODS can aid from serial MRIs as initial MRIs findings may be unrevealing [23].

\section{Treatment and prognosis}

Despite the proposal of numerous treatment methods via case series and case reports including thyrotropinreleasing hormone, plasmapheresis, steroids, and immunoglobulins; there is a glaring paucity of data due to the absence of any large-scale studies regarding effective treatment guidelines for ODS. Hence, the mainstay of treatment of ODS is supportive along with preventing the development of secondary complications [5, 24-27]. The outcome of ODS has considerable variations that include an almost complete recovery to a nominal improvement of the resultant clinical manifestations [28-29]. Most of the early studies maintained that ODS has an inevitably grave prognosis $[6,7,30]$. However, more recent studies have demonstrated strikingly distinct results [23, 31-32]. McCormick et al. indicated almost $100 \%$ mortality within three months after admission following ODS in 1967, whereas in 2011, Graff-Radford et al. showed a favorable outcome in $60 \%$ of the cases with a mortality of $8 \%$ in the acute setting [23, 33]. We postulate that rapid detection of ODS with MRI techniques and a subsequently prompt initiation of treatment, coupled with new advances in management modalities could explain the improvement in overall mortality.

\section{Normal sodium correction and ODS}

We conducted a review of the literature using PubMed to ascertain the reported cases of ODS in patients with a normal sodium correction from 2003 to 2018 . We identified a total of six cases previously reported which are summarized in Table 1.

\begin{tabular}{|c|c|c|c|c|c|c|c|c|c|}
\hline Publication & Age & Sex & $\begin{array}{l}\text { Clinical } \\
\text { presentation }\end{array}$ & $\begin{array}{l}\text { Sodium } \\
\text { concentration } \\
\text { at time of } \\
\text { presentation } \\
\text { (mEq/L) }\end{array}$ & $\begin{array}{l}\text { Rate of } \\
\text { sodium } \\
\text { correction } \\
\text { (mEq/L/day) }\end{array}$ & $\begin{array}{l}\text { Onset of ODS } \\
\text { presentation }\end{array}$ & modality & Treatment & Outcome \\
\hline $\begin{array}{l}\text { Orakzal et } \\
\text { al. [34] }\end{array}$ & 52 & M & $\begin{array}{l}\text { Jaundice and } \\
\text { confusion, } \\
\text { history of } \\
\text { alcohol abuse } \\
\text { since } 35 \text { years }\end{array}$ & 122 & $<12$ & $\begin{array}{l}\text { Deterioration of } \\
\text { mental status, } \\
\text { conscious but only } \\
\text { responding to } \\
\text { painful stimuli, } \\
\text { sluggish pupillary } \\
\text { responses, bilateral } \\
\text { upgoing plantars }\end{array}$ & $\begin{array}{l}\text { After an initial } \\
\text { unremarkable } \\
\text { MRI, a repeat } \\
\text { MRI four } \\
\text { weeks later } \\
\text { showed } \\
\text { abnormal T2 } \\
\text { prolongation } \\
\text { of the central } \\
\text { pons with a } \\
\text { lack of } \\
\text { enhancement }\end{array}$ & $\begin{array}{l}\text { Neuro- } \\
\text { rehabilitation } \\
\text { with supportive } \\
\text { care and } \\
\text { physical therapy }\end{array}$ & $\begin{array}{l}\text { Marked } \\
\text { improvement } \\
\text { in the mental } \\
\text { status and } \\
\text { the ability to } \\
\text { move all four } \\
\text { limbs }\end{array}$ \\
\hline \multirow[t]{2}{*}{$\begin{array}{l}\text { Koul et al. } \\
\text { [35] }\end{array}$} & \multirow[t]{2}{*}{47} & $\mathrm{M}$ & $\begin{array}{l}\text { Altered } \\
\text { sensorium }\end{array}$ & 94 & 8 & $\begin{array}{l}\text { Deterioration of } \\
\text { consciousness and } \\
\text { quadriparesis } \\
\text { leading to 'locked- } \\
\text { in' syndrome }\end{array}$ & $\begin{array}{l}\text { MRI revealed } \\
\text { symmetrical } \\
\text { hypointense } \\
\text { areas on } \mathrm{T} 1 \\
\text { and } \\
\text { hyperintense } \\
\text { areas on T2 } \\
\text { in the pons } \\
\text { and basal } \\
\text { ganglia }\end{array}$ & Supportive & Unknown \\
\hline & & & & & & & & $r$ & \\
\hline
\end{tabular}




\section{Cureus}

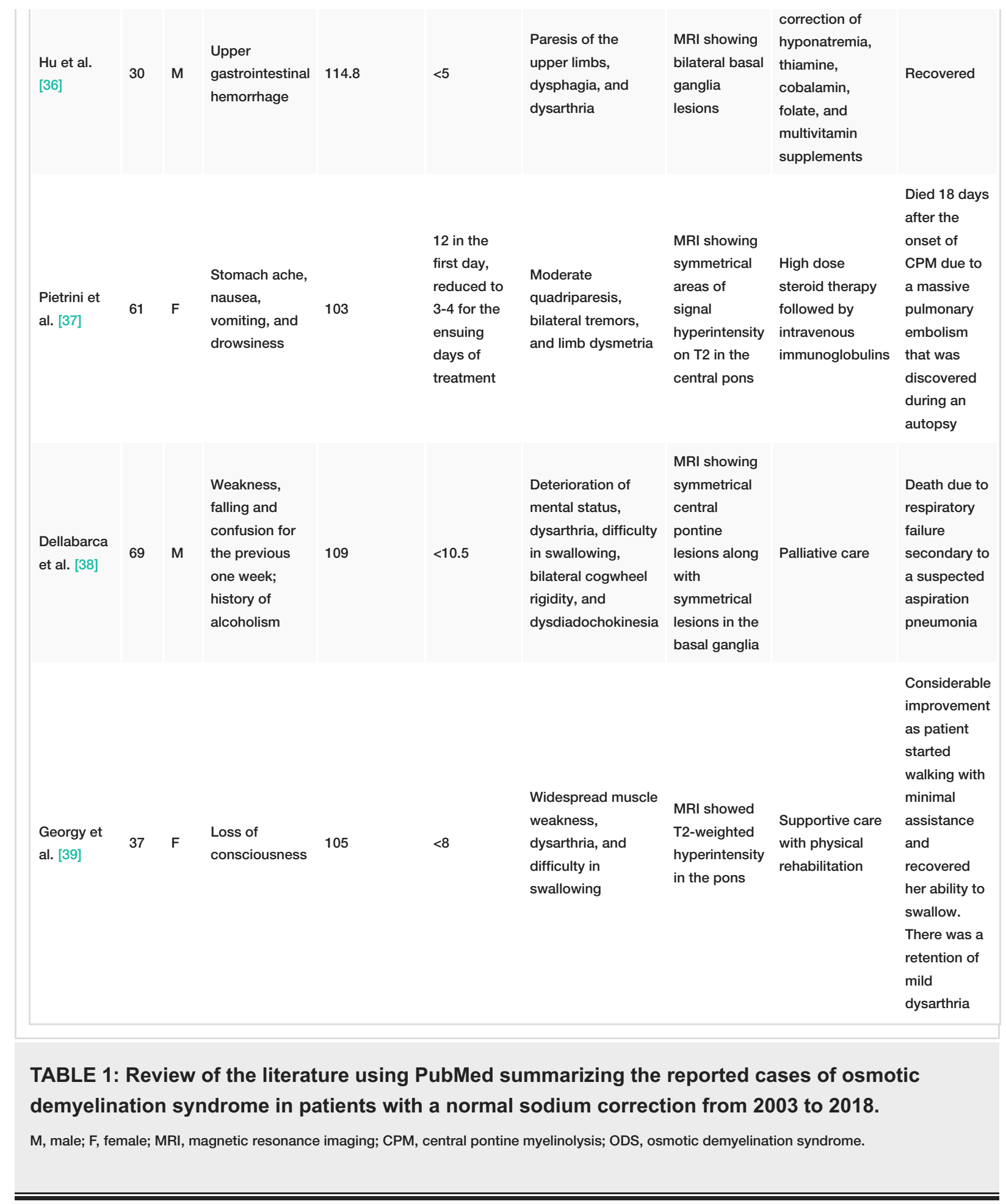

The most common presentation was that of altered mentation and loss of consciousness. Deterioration was depicted by later developments such as dysphagia, dysarthria, and paresis of the limbs. Most of the patients were managed with supportive measures. The clinical outcome was favorable in half the patients who eventually recovered while the remaining patients succumbed to the initial neurological insult.

\section{Conclusions}

Osmotic demyelination syndrome is a rare clinical entity. It has an undetermined clinical incidence with most patients diagnosed during an autopsy. The initial neurological insult occurs secondary to a rapid replenishment of sodium; however, a normal correction could also precipitate the syndrome in rare cases. Nonspecific to detrimental symptoms underscore the ambiguous nature of the clinical presentation. The MRI scans aid in the diagnosis which should be followed by prompt treatment. However, despite recent advances in clinical management, the outcomes remain obscure. 


\section{Additional Information \\ Disclosures}

Conflicts of interest: In compliance with the ICMJE uniform disclosure form, all authors declare the following: Payment/services info: All authors have declared that no financial support was received from any organization for the submitted work. Financial relationships: All authors have declared that they have no financial relationships at present or within the previous three years with any organizations that might have an interest in the submitted work. Other relationships: All authors have declared that there are no other relationships or activities that could appear to have influenced the submitted work.

\section{References}

1. Norenberg MD: Central pontine myelinolysis: historical and mechanistic considerations. Metab Brain Dis. 2010, 25:97-106. 10.1007/s11011-010-9175-0

2. Sterns RH, Hix JK, Silver S: Treatment of hyponatremia. Curr Opin Nephrol Hypertens. 2010, 19:493-498. 10.1097/MNH.0b013e32833bfa64

3. Mount DB: The brain in hyponatremia: both culprit and victim . Semin Nephrol. 2009, 29:196-215. 10.1016/j.semnephrol.2009.03.021

4. Gankam Kengne F, Nicaise C, Soupart A, et al.: Astrocytes are an early target in osmotic demyelination syndrome. J Am Soc Nephrol. 2011, 22:1834-1845. 10.1681/ASN.2010111127

5. Musana AK, Yale SH: Central pontine myelinolysis: case series and review. WMJ. 2005, 104:56-60.

6. Gocht A, Colmant HJ: Central pontine and extrapontine myelinolysis: a report of 58 cases . Clin Neuropathol. 1987, 6:262-270.

7. Adams RD, Victor M, Mancall EL: Central pontine myelinolysis: a hitherto undescribed disease occurring in alcoholic and malnourished patients. AMA Arch Neurol Psychiatry. 1959, 81:154-172. 10.1001/archneurpsyc.1959.02340140020004

8. Kumar S, Fowler M, Gonzalez-Toledo E, Jaffe SL: Central pontine myelinolysis, an update. Neurol Res. 2006, 28:360-366. 10.1179/016164106X110346

9. Sajith J, Ditchfield A, Katifi HA: Extrapontine myelinolysis presenting as acute parkinsonism. BMC Neurol. 2006, 6:33. 10.1186/1471-2377-6-33

10. Seok JI, Lee DK, Kang MG, Park JH: Neuropsychological findings of extrapontine myelinolysis without central pontine myelinolysis. Behav Neurol. 2007, 18:131-134. 10.1155/2007/980643

11. Sullivan AA, Chervin RD, Albin RL: Parkinsonism after correction of hyponatremia with radiological central pontine myelinolysis and changes in the basal ganglia. J Clin Neurosci. 2000, 7:256-259. 10.1054/jocn.1999.0192

12. Lin CM, Po HL: Extrapontine myelinolysis after correction of hyponatremia presenting as generalized tonic seizures. Am J Emerg Med. 2008, 26:632-635. 10.1016/j.ajem.2007.10.007

13. Brown WD: Osmotic demyelination disorders: central pontine and extrapontine myelinolysis. Curr Opin Neurol. 2000, 13:691-697.

14. Rojiani AM, Prineas JW, Cho ES: Electrolyte-induced demyelination in rats. 1. Role of the blood-brain barrier and edema. Acta Neuropathol. 1994, 88:287-292. 10.1007/BF00310371

15. Rojiani AM, Cho ES, Sharer L, Prineas JW: Electrolyte-induced demyelination in rats. 2. Ultrastructural evolution. Acta Neuropathol. 1994, 88:293-299. 10.1007/BF00310372

16. Adler S, Verbalis JG, Williams D: Effect of rapid correction of hyponatremia on the blood-brain barrier of rats. Brain Res. 1995, 679:135-143. 10.1016/0006-8993(95)00245-L

17. Sterns RH, Cappuccio JD, Silver SM, Cohen EP: Neurologic sequelae after treatment of severe hyponatremia: a multicenter perspective. J Am Soc Nephrol. 1994, 4:1522-1530.

18. Hadfield MG, Kubal WS: Extrapontine myelinolysis of the basal ganglia without central pontine myelinolysis. Clin Neuropathol. 1996, 15:96-100.

19. Chua GC, Sitoh YY, Lim CC, Chua HC, Ng PY: MRI findings in osmotic myelinolysis. Clin Radiol. 2002, 57:800-806. 10.1053/crad.2002.0977

20. de Souza A, Desai PK: More often striatal myelinolysis than pontine? A consecutive series of patients with osmotic demyelination syndrome. Neurol Res. 2012, 34:262-271. 10.1179/1743132812Y.0000000009

21. Hurley RA, Filley CM, Taber KH: Central pontine myelinolysis: a metabolic disorder of myelin . J Neuropsychiatry Clin Neurosci. 2011, 23:369-374. 10.1176/jnp.23.4.jnp369

22. Buis CI, Wijdicks EF: Serial magnetic resonance imaging of central pontine myelinolysis . Liver Transpl. 2002, 8:643-645. 10.1053/jlts.2002.34023

23. Graff-Radford J, Fugate JE, Kaufmann TJ, Mandrekar JN, Rabinstein AA: Clinical and radiologic correlations of central pontine myelinolysis syndrome. Mayo Clin Proc. 2011, 86:1063-1067. 10.4065/mcp.2011.0239

24. Chemaly R, Halaby G, Mohasseb G, Medlej R, Tamraz J, el-Koussa S: Extrapontine myelinolysis: treatment with TRH [Article in French]. Rev Neurol. 1998, 154:163-165.

25. Bibl D, Lampl C, Gabriel C, Jungling G, Brock H, Kostler G: Treatment of central pontine myelinolysis with therapeutic plasmapheresis. Lancet. 1999, 353:1155. 10.1016/S0140-6736(99)01145-9

26. Nishino K, Yasuda T, Kowada M: A case of central pontine myelinolysis with neurological recovery after administration of glucocorticoid [Article in Japanese]. No To Shinkei. 1991, 43:483-488

27. Finsterer J, Engelmayer E, Trnka E, Stiskal M: Immunoglobulins are effective in pontine myelinolysis. Clin Neuropharmacol. 2000, 23:110-113.

28. DeWitt LD, Buonanno FS, Kistler JP, et al.: Central pontine myelinolysis: demonstration by nuclear magnetic resonance. Neurology. 1984, 34:570-576. 10.1212/WNL.34.5.570

29. da Cunha C, Bertorini TE, Lawrence J, Witherington JM: Central pontine myelinolysis--a preventable condition. Two case reports and review of the literature. J Tenn Med Assoc. 1986, 79:469-472.

30. Ho VB, Fitz CR, Yoder CC, Geyer CA: Resolving MR features in osmotic myelinolysis (central pontine and extrapontine myelinolysis). Am J Neuroradiol. 1993, 14:163-167. 


\section{Cureus}

31. Menger H, Jorg J: Outcome of central pontine and extrapontine myelinolysis $(n=44)$. J Neurol. 1999, 246:700-705. 10.1007/s004150050435

32. Kallakatta RN, Radhakrishnan A, Fayaz RK, Unnikrishnan JP, Kesavadas C, Sarma SP: Clinical and functional outcome and factors predicting prognosis in osmotic demyelination syndrome (central pontine and/or extrapontine myelinolysis) in 25 patients. J Neurol Neurosurg Psychiatry. 2011, 82:326-331.

10.1136/jnnp.2009.201764

33. McCormick WF, Danneel CM: Central pontine myelinolysis. Arch Intern Med. 1967, 119:444-478. 10.1001/archinte.1967.00290230082002

34. Orakzai RH, Orakzai SH, Hasley PB: Treating hyponatremia: how slow is safe? Central pontine myelinolysis despite appropriate correction of hyponatremia. Eur J Intern Med. 2008, 19:29-31. 10.1016/j.ejim.2007.08.009

35. Koul PA, Khan UH, Jan RA, et al.: Osmotic demyelination syndrome following slow correction of hyponatremia: possible role of hypokalemia. Indian J Crit Care Med. 2013, 17:231-233. 10.4103/09725229.118433

36. Hu Q, Zhang C, Liu J, Xu F, Zhu S: Extrapontine myelinolysis in a case of portal cavernous transformation following slow correction of chronic hyponatremia. Neurol Sci. 2013, 34:1831-1833. 10.1007/s10072-0131311-2

37. Pietrini V, Mozzani F, Crafa P, Sivelli R, Cademartiri F, Crisi G: Central pontine and extrapontine myelinolysis despite careful correction of hyponatremia: clinical and neuropathological findings of a case. Neurol Sci. 2010, 31:227-230. 10.1007/s10072-009-0173-0

38. Dellabarca C, Servilla KS, Hart B, Murata GH, Tzamaloukas AH: Osmotic myelinolysis following chronic hyponatremia corrected at an overall rate consistent with current recommendations. Int Urol Nephrol. 2005, 37:171-173. 10.1007/s11255-004-4770-9

39. Georgy V, Mullhi D, Jones AF: Central pontine myelinolysis following 'optimal' rate of correction of hyponatraemia with a good clinical outcome. Ann Clin Biochem. 2007, 44:488-490. $10.1258 / 000456307781646067$ 